\title{
FIJIAN SIGIDRIGI AND THE SONIC REPRESENTATION AND CONSTRUCTION OF PLACE
}

\author{
Transforming Cultures eJournal, \\ Vol. 4 No 1, April 2009 \\ http://epress.lib.uts.edu.au/journals/TfC
}

\section{Jennifer Cattermole ${ }^{1}$}

\begin{abstract}
This paper explores how the inhabitants of Taveuni, Fiji's third largest island, use the music genre known as sigidrigi (from the English 'sing drink') to articulate and redefine their relationships to particular places. Sigidrigi songs are often performed by groups of men to entertain people during informal yaqona (or kava as it is known throughout Polynesia) drinking sessions. They feature three or four-part vocal harmony, and are accompanied by guitar and/or ukulele. The repertoire consists of covers and localised versions of overseas songs, as well as songs composed by Fijians in styles adopted and adapted primarily from Northern America and Western Europe (for example, rock, pop, country and blues). The repertoire also includes songs from other Pacific islands, the Caribbean (for example, reggae), Indo-Fijian songs, and $i$ taukei (indigenous Fijians of Melanesian or Polynesian descent) children's songs and meke (an art form consisting of music, dance and costuming whose origin pre-dates European contact). An examination of sigidrigi song lyrics (in terms of both language use and textual content), band names, and various elements of musical style (such as texture, timbre, meter etc.) reveals how Taveuni islanders have used this music genre to (re)construct communities at geographical scales ranging from the local to the supranational.
\end{abstract}

\section{Introduction}

This article explores how $i$ taukei (indigenous Fijians of Melanesian and/or Polynesian descent) $)^{2}$ use the Fijian music genre known as sigidrigi (derived from the English terms 'sing-drink') to articulate and redefine their relationships to particular places. After

\footnotetext{
${ }^{1}$ Jennifer Cattermole teaches at the University of Western Sydney.

${ }^{2}$ For an individual to be considered an indigenous Fijian, their name must be recorded in the vola ni kawa bula. People whose names are not recorded in this book must lease or purchase land. Indigenous is a politically charged term, with emotional/psychological implications regarding a person's sense of legitimacy of belonging to the land. Indigeneity involves the autochthonous claims of Fiji's Melanesian and Polynesian population. Following the wave of immigration that followed Fiji's colonization by Britain, the descendents of subsequent immigrants to Fiji (including those from other islands in the Pacific, as well as those from Europe and Asia - some of whom can trace their family's history back generations in Fiji) are excluded from being categorized as indigenous.
} 
briefly introducing some of the processes of adoption and adaptation that have occurred in sigidrigi performance and composition, this article examines sigidrigi's debated status as a local music genre by emphasising points of continuity and discontinuity with pre-European contact Fijian music. An examination of sigidrigi band-naming practices, song lyrics (in terms of both language use and textual content), and various elements of musical style reveals how this genre has been used to (re)construct real and imagined communities at geographical scales ranging from the local to the supranational.

The theoretical underpinnings of this article are drawn from cultural geography, ethnomusicology and popular music studies, while the raw data is derived primarily from field research conducted on the neighbouring islands of Taveuni and Qamea, which I undertook from March to September 2005 and from mid-December 2005 to February 2006.

\section{Adoption and adaptation}

Taveuni and Qamea are both remote from the socio-economic and music industry base of Viti Levu. Media and transportation technologies have nevertheless had a significant impact on these islands' cultures. The Fijian popular music genre known as sigidrigi has arisen as a result of various intersecting global flows of music. ${ }^{3}$ Taveuni and Qamea composers tend to utilise the styles that are currently popular in their songs. These include covers and adaptations of styles from Western Europe and Northern America (such as the major international varieties of rock in the 1980s and 1990s, country and western, pop and hip hop), as well as the Caribbean (reggae in particular). ${ }^{4}$ The repertoire also includes songs adopted from Indo-Fijians, Aotearoa/New Zealand Mäori, Banaban/Ocean Islanders, Hawaiians, Tongans, and Papua New Guineans. So how, then, have these overseas styles been selectively adopted and adapted and used to articulate and (re)construct local identities?

\footnotetext{
${ }^{3}$ This can be seen in the interactions that occur between $i$ taukei and overseas visitors. This can occur when $i$ taukei musicians travel overseas, or when they interact with overseas musicians in Fiji (or example, tourists staying in resorts and villages, as well as overseas exchange students). Recording technologies have also had a tremendous impact on the repertoire and performance techniques used by $i$ taukei.

${ }^{4}$ See Goldsworthy, 1998: 161-2
} 
Local covers of overseas songs often closely approximate the originals. The lyrics (including the references to non-local placenames) often remain unmodified, and the singers often use the same vocal harmonies and melodies. Singers may even imitate the vocal delivery of the original singer to the extent of mimicking the accent used by the original artists - particularly in the case of country and reggae songs.

However, localisation also occurs. ${ }^{5}$ Solo songs and duets may be rearranged so that they can be performed by trio ensembles, and the instrumental lines are often adapted and arranged to suit the range of instruments available as well as the stylistic preferences and playing abilities of Taveuni and Qamea musicians. The lyrics of overseas songs are sometimes translated into Standard Fijian, with varying degrees of fidelity to the original text (please see table 1 below). Additionally, the setting of new lyrics to existing overseas (as well as local) tunes is regarded as being a perfectly legitimate form of composition on Taveuni and Qamea, although composers stress that the new lyrics should be similar in meaning ( $i$ balebale) to those of the original song (please see table 2 below).

\begin{tabular}{|l|l|l|}
\hline Title of Fijian translation & Original song title & Original composer(s) \\
\hline Isa lei Lia & Leah & Roy Orbison \\
\hline Nanuma lesu & Wonderful tonight & Eric Clapton \\
\hline Vale ni tui & All I have to offer you is me & Dallas Frazier \\
\hline Oqo na gauna & Now is the hour & $\begin{array}{l}\text { Clement Scott, Maewa } \\
\text { Kaihau, and Dorothy } \\
\text { Stewart }\end{array}$ \\
\hline Sa moce na rosi daulomani & Goodbye England's rose & $\begin{array}{l}\text { Elton John and Bernie } \\
\text { Taupin }\end{array}$ \\
\hline
\end{tabular}

Table 1: Examples of overseas songs translated into Standard Fijian

\section{\begin{tabular}{|l|l|l|}
\hline Title of Fijian adaptation & Original song title & Original composer(s) \\
\hline
\end{tabular}}

\footnotetext{
${ }^{5}$ The localisation of overseas popular songs has most likely been occurring since these songs were first introduced to Fijian audiences. There are several documented instances of popular song localisation in the literature pertaining to Fiji. For example, Teeling (1936: 125) describes a performance at Nanukuloa, in which "one man after another did his special dance for me, and three boys, garlanded, sang to the accompaniment of their guitars, songs that only slightly differed from Hawaiian airs, so that even 'God save the King,' transposed to suit Fijian music and in their language, sounded romantic and very sad." Whorson Aston (1936: 49) describes taralala dancing being accompanied by a tune "which was almost to be identified with Polly Wolly Doodle with barbaric effects." Brewster (1922: 93-4) provides the Fijian text and its English translation of the chorus from "Marching through Geogia." The Fijian rowers of the 'Kearsage' learnt this during a visit to Suva, and Brewster notes that "the Suva boys were very proud of this accomplishment and used to march about in bands on the beach singing it for our delectation." Raven-Hart (1956: 140), writing about the Yasawas, indicated that a "very little altered" version of "Rio Grande" was popular. The setting of new texts to existing tunes also occurs in New Guinea (see Chenoweth, 1998b: 357), and Irian Jaya (see Chenoweth, 1998a: 360).

${ }^{6}$ A detailed summary of this song's genesis can be found at: http://folksong.org.nz/poatarau/index.html
} 


\begin{tabular}{|c|c|c|}
\hline Dua na bogi & You are my sunshine & $\begin{array}{l}\text { Jimmie Davis and } \\
\text { Charles Mitchell }\end{array}$ \\
\hline Draki vinaka & Mockingbird hill & Vaughn Horton \\
\hline E na noqu gade voli & Nobody's child & Cy Coben and Mel Foree \\
\hline Irene na luvequ & Let it be & Paul McCartney \\
\hline Kabi voleka & He'll have to go & Joe and Audrey Allison \\
\hline Kavoro ni utoqu & It's now or never & $\begin{array}{l}\text { Aaron Schroeder and } \\
\text { Wally Gold }\end{array}$ \\
\hline Noqu nanuma luvuci e noqu & Could I have this dance? & $\begin{array}{l}\text { Wayland Holyfield and } \\
\text { Bob House }\end{array}$ \\
\hline Noqu rosi na mosi vei au & Pretty woman & $\begin{array}{l}\text { Roy Orbison and Bill } \\
\text { Dees }\end{array}$ \\
\hline Rui domoni vei au & $\begin{array}{l}\text { I can't help falling in love } \\
\text { with you }\end{array}$ & $\begin{array}{lcc}\text { George } & \text { Weiss, } & \text { Hugo } \\
\text { Perretti, } & \text { and } & \text { Luigi } \\
\text { Creatore } & & \\
\end{array}$ \\
\hline Siga ni sucu & A fool such as I & Bill Trader \\
\hline Vakadagava & $\begin{array}{l}\text { Listen to the rhythm of the } \\
\text { falling rain }\end{array}$ & John Gummoe \\
\hline Mosi vei au & I can see clearly now & Johnny Nash \\
\hline Yaloqu mo sa qai sivia & Mexican girl & $\begin{array}{l}\text { Chris Norman and Pete } \\
\text { Spencer }\end{array}$ \\
\hline
\end{tabular}

Table 2: Examples of newly-composed texts in Standard Fijian set to the existing tunes of overseas songs

\section{Sigidrigi's roots}

Having very briefly outlined some of the ways in which overseas songs have been adopted and adapted, I now want to examine sigidrigi's status as a 'local' music genre by comparing it with meke (an art form dating from pre-European contact times incorporating dance, poetry, costume and music; performed mainly on formal occasions). There are two main styles of sigidrigi currently performed on Taveuni and Qamea: sere bass and trio. Sere bass, the older style of sigidrigi, began going out of fashion with the introduction of trio in the mid-1990s. In several respects, sere bass is stylistically closer to meke than trio. There are marked stylistic differences between these two styles, and the nature of these stylistic changes reveals a movement away from musical roots to an exploration of musical routes. Some of the changes that have taken place (in terms of the vocal parts, vocal performance practice, performance context, the formation of the performers, instrumentation and song texts) are outlined below.

Melodically and tonally, sere bass bear some similarities to meke. Although the vocal harmony of sigidrigi songs resembles that of SATB European choral music, both Lee 
(1998: 779) and Glamuzina (1993: 171) found that the names and structural roles of the vocal parts in sigidrigi were derived from those used in meke. The laga/lagalaga (the leading voice) and tagica/tarava (a higher-sounding part) were both sung solo, while the $d r u k u / g u d r u$ part was sung by a large group of bass singers. ${ }^{7}$ In addition to these parts, participants in this research identified a third solo voice (domo tolu, va'ababa or tena), which fits structurally between the other two solo voices. Only the three solo voice parts are used in trio. In comparison to meke and sere bass, the register of the vocal parts used in trio performances tends to be higher, and greater tonal variety is employed (meke and sere bass performances tend to remain in one tonal area for the duration of the evening).

The performance context and vocal style has also changed over time. Like meke, sere bass performances (usually) take place outdoors. Anyone can participate in the singing of sere bass, and the vocalists sing loudly - almost straining their voices. In comparison, the performance of trio songs is much more exclusive, and a greater degree of musical proficiency is expected. As performances typically take place during informal indoor yaqona ${ }^{8}$-drinking gatherings, the vocalists sing more quietly.

The performance formation used for sigidrigi performance also has its roots in meke. In sere bass, the members of the matasere tend to sit together in a cluster, with the instrumentalists and solo singers near the centre. Goldsworthy (1998: 162) notes that this formation is also typical of meke. Although trio performers also tend to sit in a roughly circular formation, ${ }^{9}$ resort performers may sometimes perform standing in straight lines while serenading diners ${ }^{10}-$ a marked departure from tradition.

The same instruments used for meke performance were also initially used in the performance of sigidrigi. According to early accounts, informal sere were performed

\footnotetext{
${ }^{7}$ Taveuni islanders used a range of terms to describe these parts. The main vocal part was identified as the laga, lagalaga or soprano. The other solo part was named tatabani, tabana, tatabana, tagica, domo lailai, domo va'ayalewa, camena, second or alto. The bass part was called bass, besi or domo besi.

${ }^{8}$ Yaqona (known as kava throughout Polynesia) refers to the plant Piper Methisticum. The roots and stems of this plant are dried and then pounded (masticated in the past), made into an infusion and then drunk.

${ }^{9}$ They may sit partially facing one another as part of the larger circle of people gathered to drink yaqona, or they may be seated apart from the main group. At large social gatherings, they may even be drinking from their own beseni or tanoa.

${ }^{10}$ This occurred, for example, at the Qamea Island Resort and Spa (4/6/05), and at performances at the Maravu Resort.
} 
unaccompanied, or accompanied by instruments such as lali ni me'e, derua (called bitu on Taveuni) and body percussion (cobo and sau handclapping). Introduced chordophones were introduced into these ensembles. Eventually the percussive, rhythmic function of the lali ni me'e and derua was taken over by the rhythm guitar and ukulele, while the functions of the mandolin and wa dua (one-stringed tea-chest bass) have been transferred to the lead and bass guitars.

Textually, there are several similarities between meke texts and those of sere bass. As in meke, end-rhyme is a feature of sigidrigi song texts - although its use varies in consistency. Some sigidrigi songs feature narrative texts containing poetic imagery and symbolism typical of old meke and pre-European lyrics elsewhere in Oceania (Goldsworthy, 1998: 162). An example of this is the phrase kato ni sere me sa na sogo mada (the song chest is to be closed) from the song "Home buru" composed and performed by the Maravu Band Boys (the resident band at the Maravu Plantation Resort, Taveuni). Like meke, metaphor and simile are used extensively in sere bass, whereas the language used in trio songs tends to be more literal. The subject matter of sere bass also tends to be more similar to meke than trio. Sere bass tend to be about historical events and celebrations (such as festivals), myths/legends, flora and fauna, prominent public figures (for example, politicians such as Ratu Sukuna), and deities. Trio songs, in comparison (like many contemporary Western pop songs), are about love.

Given that several elements of sigidrigi performance appear to be derived from meke antecedents, does this music genre enable $i$ taukei performers and audience members to index their cultural roots and musically establish a sense of Fijian identity? Several musicians that I spoke with asserted that sigidrigi is a valued aspect of Fijian cultural heritage. This informal village music genre is currently the oldest form of popular music in Fiji (Goldsworthy, 1998: 161). For musicians who can trace sigidrigi performance back 2-3 generations in their family, this music represents a 'traditional' activity - albeit a recently invented one (see Hobsbawm and Ranger, 1983). Some musicians ascribe a sense of authenticity to sigidrigi - asserting that sigidrigi is "the real thing" (Petero Naiqama, p.c. 29/4/05) or that "this is Fijian music" (Sirilo Seru, p.c. 21/7/05). However, the validity of sigidrigi's status as a 'roots' music is up for debate. For 
example, Leone Ranuve (p.c. 21/7/05) stated that "sigidrigi is not real Fijian music" due to the use of introduced instruments. ${ }^{11}$

In comparison to meke, sigidrigi is much less closely associated with concepts of tradition and identity, and is regarded as having considerably less social and cultural significance. ${ }^{12}$ Meke is viewed as being more authentically Fijian than sigidrigi, and thus as having greater importance in creating and sustaining $i$ taukei identities. Because its origins pre-date European contact, meke is seen as being distinctly local in origin (even though acculturated versions of meke are performed by students at the Adi Cakobau School and the Nasinu Training College). Meke performances are obligatory during the formal parts of Fijian ceremonies. Additionally, meke are regarded as part of the traditional cultural wealth (i yau) of particular yavusa (clans) and may only be performed by non-yavusa members with the turaga's permission.

In contrast, sigidrigi are performed during informal social gatherings, and their performance is optional - indeed, nowadays, recorded alternatives are often used as a substitute for live sigidrigi performance. Musicians tend to discuss sigidrigi in a rather depreciatory way, as being an activity that they do just to relax and have fun. During my fieldwork, musicians often queried my interest in this genre, and expressed surprise that an 'ai vulagi (foreigner) would deem it a worthwhile research topic. ${ }^{13}$ Sigidrigi was not as overtly associated with $i$ taukei identity construction and maintenance as meke. However, if the length of time a genre has been performed in a particular locality is a criterion when judging its authenticity, it is possible that sigidrigi may come to assume

\footnotetext{
${ }^{11}$ However, Leone did consider sere ni lotu to be Fijian music, even though this music genre has also been adopted. Similarly, Crowdy (2005:26) refers to two Papua New Guinean genres, ute (secular vocal) and peroveta (sacred vocal), that are regarded as being traditional, when they are in fact locally modified and developed forms of introduced musics.

${ }^{12}$ Crowdy (2005: 24) indicates that the perception of stringband music in relation to older Papua New Guinean genres is similar: "particularly among university music students I have noticed a strong perception between popular music being associated with change, and with traditional music being associated with a lack of change, or at least a great deal more resilience and resistance to it. As a result, the notion of stringband music as a tradition in itself can easily be underplayed."

${ }^{13}$ Crowdy (2005: 113) experienced a similar reaction in regard to his research on Papua New Guinean stringband music: "many students have described to me their perception of stringband as being a grassroots village style, focussing comments on a perceived lack of musical sophistication. One might expect such a view from students who form part of an educated elite in Papua New Guinea, particularly when speaking to a lecturer from overseas such as myself. I sense this is an attempt to distance themselves from musical practices they perceive as being of little importance outside purely local contexts. As a lecturer in music, my own interest in stringband music has often been regarded with a combination of amazement, amusement, disdain or outright confusion by some students" (see also Webb, 1993: xix).
} 
greater value as part of Fiji's intangible cultural heritage due to its more recognisably localised aspects in comparison to programme music ${ }^{14}$ and overseas recordings.

\section{Sigidrigi and the construction of local identities}

Having addressed some of the stylistic elements of sigidrigi and their significance in terms of $i$ taukei senses of place and identity above, I now wish to spend the remainder of this article focussing primarily on sigidrigi lyrics (in terms of the linguistic and textual content) and band names. By doing so, I by no means wish to infer that these elements of sigidrigi performance are more important than factors such as harmony, melody, timbre, dynamics, tempo, rhythm, and texture. They do, however, offer a high degree of specific meaning to audiences.

Before discussing in greater depth how sigidrigi is used to reflect and construct Taveuni and Qamea Islanders' senses of place and identity, it is first necessary to briefly explain the meaning of the term vanua. This multifaceted concept denotes social groups that have a shared allegiance to a recognised authority and shared ideologies and practices. However, it not only refers to $i$ taukei social and political relationships, but also to their relationships with flora and fauna, the physical environment, and the supernatural realm. As Asesela Ravuvu discusses in his book Vaka i Taukei: the Fijian Way of Life:

The Fijian term vanua has physical, social and cultural dimensions which are interrelated. It does not mean only the land area one is identified with, and the vegetation, animal life, and other objects on it, but also includes the social and cultural system - the people, their traditions and customs, beliefs and values, and the various other institutions established for the sake of achieving harmony, solidarity and prosperity within a particular social context. Its social and cultural dimensions are a source of security and confidence. It provides a sense of identity and belonging. One feels good and comfortable when he [sic] feels that he belongs to a particular vanua or social unit identified with a particular territorial area in which its roots are established. It is the place where he or his forbears were born and brought up, and where he prefers to die. In its spiritual dimension, it is a source of mana or power to effect things. It is the place where his ancestors preceded him and in which their spirits or souls linger and watch over the affairs of those who came after them. The vanua contains the actuality of one's past and the potentiality of one's future. It is an extension of the concept of the self. To most Fijians, the idea of parting with one's vanua is tantamount to parting with one's life (1983:70).

\footnotetext{
${ }^{14}$ The term 'programme music' is derived from the use of programmed or sequenced keyboard-generated instrumental accompaniment. Programme music songs tend to feature the use of an adapted reggae beat.
} 
The people are the lewe ni vanua (the flesh / members of the land); the human manifestation of the physical environment. The land belongs to the people, and the people belong to the land. Land is seen as being lifeless and useless without people. To become identifiable to other social groups, a vanua (land, in both its physical and social dimensions) must have people living on it, supporting it, defending its rights and interests, and exploiting its resources. Likewise, the people are helpless and insecure without land to thrive upon. They are dependent on the land for nourishment, shelter, protection, and for a sense of identity and belonging. Particular vanua have substantiated their ownership claims to particular areas - qele ni teitei (gardening land), veikau (forest land), yavutu (founding ancestor's house sites) and qoliqoli (fishing areas). The rights to use these areas are granted by the Native Land Commission, and vested in particular mataqali (Ravuvu 1983:76-7).

Sigidrigi songs are one of the means by which $i$ taukei represent, and thereby construct, their sense of who they are and where they belong. By reinforcing the links between particular kinship groups and their home places, these songs are a means of inscribing places with meaning and value. There are numerous examples of songs that highlight the importance of kinship networks and place as signifiers of $i$ taukei identity. These include a song entitled "Tinaqu" ("My mother"), which commemorates the death of a woman named Ilisabeta. The lyrics of the fourth verse of this song are as follows:

Vugalei nomu yavu ni vosota meu cavuta

Wiwi nomu koro ko susugi mai kina Ko vakawati i Vunikura mataqali Nadaraga You married into Vunikura in the sub-clan
Nadaraga

I na yavusa ko Mabuco tokatoka ko Nacawa In the clan of Mabuco and sub-clan of Nacawa
Vugalei your yavu, forgive me for mentioning / pointing out

Wiwi your village you were brought up in

To take another example, the final lines of the song "Ni vakarorogo saka mada" ("Just listen to me my relatives"), a song composed about the sprinter Jale Turaga Damudamu by his uncle, state:

\section{Kere veivosoti niu mai cavuyaca}

Na nomu yavusa tabu ko Nasamuwaga Kei na mataqali Vunibua rogo yawa Au loloma levu yani ki lomai Dawara
I beg your pardon, for I am going to mention a couple of names

Your clan, Nasamuwaqa

And the sub-clan Vunibua, famous

My big regards to Dawara 
In both of these excerpts, the composers ask for the audience's forgiveness prior to mentioning the names of people's home places. ${ }^{15}$ This is a rhetorical convention employed in sigidrigi songs, and is also sometimes used prior to mentioning the names of individuals. In both instances, it signifies that the names ( $i$ cavuti) being mentioned are regarded as tabu (sacred, highly respected). Both of these examples also show how songs that name particular individuals usually identify that individual as belonging to a specific tokatoka (sub-lineage, extended family), mataqali (agnatically related sub-clan or lineage), yavusa (clan whose members claim descent from a common founding male ancestor), and/or vanua (tribe) as part of the song's narrative.

Every mataqali has three totems which are symbolic of its identity: a native tree, land animal (or bird) and sea animal. Song lyrics as well as band names may refer to one of these totems to signify the identity of the composer and/or performing group. For example, the song "Navucu" ("The chant") refers to the native tree that is the symbolic of a particular mataqali from the island of Qamea in the line "Noqu kau yaga vuasea qori dau boi yawa" ("My tree vuasea which can be smelt far away"). In this line, the words "which can be smelt far away" do not necessarily mean that the vuasea is a particularly aromatic type of wood. Rather, they are a metaphor implying that the mataqali in question is widely respected. Band names may also refer to one of these totems as a signifier of the group's identity. For example, the Vuanimaba trio (a group from Qeleni, Taveuni), are named for the vuanimaba - the name of the fruit of the tree that is one of their mataqali's totems. Likewise, a group from Kocoma village on the neighbouring island of Qamea (which has kinship affiliations with Qeleni) named themselves Vola Siga kei Vuanimaba (morning star of the vuanimaba).

Sigidrigi songs also often mention the villages or settlements where those individuals grew up, married or died. Emphasising the link between a person and their home(s) in these songs reinforces the importance of particular places to people's sense of identity. The various 'home' places they may be identified with include their:

- Yavu (ancestral house foundation)

- Dela ni yavu (mountain associated with their yavu)

15 This also occurs in songs such as "Maravu," "Adi Savusavu," "Matei Police Post," "Delana mudremudre," "Ni sa bula vinaka," "Ni sa bula," "Dua ciwa ono saiva na yabaki" and "Ologi." 
- Koro ni vasu (mother's village)

- Koro (village)

- Baravi (coastal area)

- Tikina (district)

- Yasana (province)

- Yanuyanu (island, or island group)

While most of these terms are fairly self-explanatory, the significance of the terms koro ni vasu and yavu require further explanation. It is customary for women to relocate to their spouse's village upon marriage, hence the significance of koro ni vasu to $i$ taukei. The term yavu denotes ancestral house foundations and their bordering areas. These foundations consist of raised earth mounds, which may be surrounded by a stone wall (tuvatuva). The higher the foundation, the higher the family's social standing in the community. The foundation normally belongs to the eldest male descendant of the first occupants, and the occupation of a yavu originally occupied by one's ancestors and dating back to the village's establishment legitimises one's relationship with the koro. New houses may be erected on old foundations, but permission to do so must be first sought from the mataqali. New yavu are constructed, with due ceremonial rites, usually within the area occupied by a particular mataqali. The remains of the original occupants may be interred within the house foundations of a mataqali's founding ancestor (yavutu). The site is therefore regarded as being imbued with magico-religious power, and as being symbolic of mataqali identity and belonging. Any disturbance to the site is believed to result in misfortune, disaster, affliction or death to the transgressors, their relatives, or to members of the mataqali, in which case ceremonial atonement to the ancestral gods/spirits ( $v u$ ) must take place (Ravuvu 1983:14, 74-5, 81).

The significance of place to $i$ taukei identity is further demonstrated through the valorisation of particular places in song as well as in band names. For example, there are several sub-categories of sigidrigi songs devoted to particular places, including:

- Sere taki ni dua vanua (songs describing particular places)

- Sere ni volo ni vanua (songs about mountains)

- Talanoa ni drano or sere ni drano (stories/songs about lakes)

- Sere ni koro (songs about villages)

- Sere ni dua baravi or sere ni baravi (songs about coastal areas)

- Sere ni yanuyanu (songs about islands) 
Place-names are usually specified in sigidrigi song lyrics, although monikers are sometimes used to refer to refer to particular places (for example, Taveuni is referred to as the garden, fertile or abundant island, Burotokula as the island of dreams, and Lautoka as the sugar city). Islands are usually geographically situated with reference to neighbouring islands in the archipelago. However, their positions are sometimes only inferred (for example, 'the south' implies Kadavu Island; 'the centre' refers to the Lomaiviti group; 'the direction of the sunrise' refers to the Lau group; and that of the sunset to Viti Levu, the Mamanucas and Yasawas).

Songs are sometimes localised to make them meaningful for particular audiences. For example, the song "Isa noqu koro" composed by Aselemo from Tavuki, was localised by Simone Vala from Navakawau through the composition of new lyrics set to the same tune (the respective differences between the two texts are highlighted in bold).

\section{Verse 1}

Isa noqu koro meu tukuna mada Isa $\quad$ Is ${ }^{16}$ my village, let me tell you Tavuki mai Taveuni / sai Navakawau oqori Tavuki from Taveuni / Navakawau is na yacana

Lako mada mai ka mo mai sarava the name Toka mai/e delana ka sarava tu na wasa Come and take a look Verse 2

Dau / Dau i gadigadi vinaka ka/e totoka ka Good sightseeing and very perfect daumaka

Veiwali kei na lasa e ra dau / ko na mai The jokes and the fun, you will come taleitaka to like it / that they will enjoy

Lako mada mai ka mo mai sarava/Nomu Your send off to your area, come and i talanoa lesu ki na nomu yasayasa watch / It will be your story when you go back to your area

Bula mamarau ka sega na kena i yalayala Joyful life with no ending / The name of / Yaca ni noqu koro au sureta mo mai sarava

Verse 3 (composed by Simone)

Dau i vakavakacegu nodra na tamata

Era bau mai na koro ni cakacaka

Turaga na marama mai na veivei yasana

Isa noqu koro era laki tawana my village, you are invited to come and observe

It is a place where people come to have a restful/pleasant time Those who come from the workplace ${ }^{17}$ Gentlemen and ladies come from different provinces

\section{Verse 4}

Isa lei Tavuki / Navakawau ko na tawaguilecavi

Isa my village, they come and fill it up

Isa lei Tavuki/Navakawau you will never be forgotten

\footnotetext{
${ }^{16}$ Isa is an expression of feelings of sorrow/sadness/pity.

${ }^{17}$ Many retirees choose to settle in Navakawau, a village surrounded by estates - perhaps because it is a place famous for its hospitality, or because their children marry there.
} 
Dau tagica / Tagica na yaloqu e na noqu tui tu / yawa tani

Niu liaca voli nai vakarau ni lasa

Moce isa Tavuki ko na tawa oti rawa
My soul cries when I am far away / as I stay far away

I miss the fun ways

Goodbye, isa Tavuki, you will not end/

\section{/ Bula mamarau sa sega na kena i yalayala Life full of unending happiness}

It is common for audience members to draw attention to themselves (for example, by waving their hand in the air) when they hear their home place mentioned. Bands also often name themselves after their villages (for example, the Lagiloa Band Boys, the Bucalevu Blues, the Qeleni Old Timers, the Nayavu Swingers and so on).

Sigidrigi song lyrics valorise prominent natural landmarks (such as mountains, lakes and rivers). Songs such as "Taveuni," composed by Vilimone Kabu, celebrate features of the landscape such as the Tevoro Falls in the Bouma National Heritage Park, the $180^{\text {th }}$ Meridian marker, the airport at Matei, the 50-foot cross that stands on a hill above the settlement of Wairiki, Taveuni's highest mountain (Mount Uluiqalau), and the lighthouse near Vuna.

\section{$\underline{\text { Verse } 1}$}

Noqu yatu yanuyanu meu sereka Meu yatu na wale vaka lekaleka My group of islands, let me share/unfold it Viubani kei Qamea, Laucala vei taravi Let me share it out shortly Viubani and Qamea, Laucala in line / one after the other in succession ${ }^{18}$

Ko Yacata e laki kabu yawa yani Yacata is covered with mist far away

Verse 2

Wainikeli e dau tadrava na tokalau

Kenai divi e na savu e matalau

Wainikeli ${ }^{19}$ facing the south

Kenai kuri na vei nuku vulavula qai balavu

Ra taukena na voivoi matalau

It is admired for its waterfalls

In addition, the long white sandy beaches

They own the quality pandanus

Vatu wale na daku ni yanuyanu

The back of the island is rocky ${ }^{20}$

Chorus

Mai rukuna na rara ni waqavuka

Ko Matei e kilai e vuravura

From the side is the aeroplane field

Verse 3

Welagi e latia na vei delana Matei, known around the world ${ }^{21}$

Vatu'ulo nodra koro na turaga

Welagi separates the mountains ${ }^{22}[$ in the middle]

Vatu'ulo the chiefly village ${ }^{23}$

\footnotetext{
${ }^{18}$ These are the islands above Taveuni

${ }^{19}$ Wainikeli is the name of the Northern district of Taveuni.

${ }^{20}$ The Eastern side of the island, from Naba (just south of Lavena) to Salialevu is mostly uninhabited because it is so mountainous.

${ }^{21}$ This line expresses that Matei is a well-known landmark, known to the world of travelers.

${ }^{22}$ Welagi is surrounded by mountains.
} 
Ko Lamini, Somosomo mai delana e davo koto

Vuniduva nai lati ni wasa ko Somosomo

Verse 4

Lovonivonu ki Waiyevo e rai yawa

Korolevu na noqu yanuyanu vinaka

Nailotua e toka kina

Na veimama ni veisiga, dua walu saiva dina na matanifika

Mai rukuna noqu koro e toka kina

Verse 5

Vale ni cina e yadra toka mai na ceva

Waqa le levu, lailai kece e vukea

Salialevu, Navakawau, mai cake ko

Kanacea

Koro ko Vuna dina qori na noqu seda

Second chorus

Uluiqalau na veibuca e rukuna

Na koruse e Wairiki e vulavula

Verse 6

Noqu koro na koruse e yadrava

Mai delana na turaga ni Delaivadra ${ }^{26}$

Savuwaqa kei Narusa ko Fatima mai rukuna

Navarada, Baniose, Mudre e rukuna

Oqori dina na vakayatuyatu ni noqu vanua
Lamini, Somosomo, from the

mountain tops lie

Vuniduva, the middle of the Somosomo strait

Lovonivonu and Waiyevo look very far away

Korolevu, my good island

Nailotua is in it

Half of every day, $180^{\text {th }}$ meridian

truly

Beside it my village is situated ${ }^{24}$

The lighthouse is watching from the East

It helps all the big and small boats

Salialevu, Navakawau, from the

top is Kanacea

Vuna village is my true centre ${ }^{25}$

Uluiqalau mountain and the valleys underneath

The cross in Wairiki is white

The cross standing there watching over / protecting the area

From the top are the gentlemen of Tavuki

Savuwaqa and Narusa, Fatima is

below

Navarada, Baniose, Mudre is below

That is truly the song/poetry of my land

The names of particular landmarks are also often incorporated in the names of local bands. For example, a band from Lavena was named Drano ni Tagimoucia (Lake Tagimoucia); Caucau ni Delai Narova (cool breeze blowing from Narova mountain to the coast) was the name of a band from Naselesele; while Miramira ni Vatuloa

\footnotetext{
${ }^{23}$ This is where the Tui Cakau resides (at the time this song was composed, the Tui Cakau was Ratu Josefa Lalabalavu).

${ }^{24}$ Nowadays, the $180^{\text {th }}$ meridian marker is placed at Lesuma. When this song was written, the marker was much closer to Wairiki (on the roadside near to the sea).
${ }^{25}$ This line refers to the home of two of the band members of Siga tu e vei - Siri and Dut. This group were a loose association of singers. Verse six mentions the names of the homeplaces of other members of the band. Brothers Poe and Tomasi Campbell are from Mudre. Farasiko was from Baniose. Farasiko Tupara is a very talented musician, who could take any voice part from bass to soprano. He used to play at the Reef Hotel (now called the Reef Resort) near Sigatoka, and has performed as a professional musician in Australia. He is currently residing in Suva and now only plays church music with Qase ni koro ni lotu.
${ }^{26}$ Delaivadra is the name of the vanua of the people of Tavuki village.


(sprinkling of Vatuloa) is the name of a group from Waitabu named after Vatuloa - the rocky point along the beach to the left of the village, at which at a freshwater spring is located.

With the exception of mentioning a person's yavu, references to sacred or semi-sacred sites (vanua tabu) ${ }^{27}$ in sigidrigi song lyrics are scarce. Nevertheless, the song "Na vucu" contains a reference to the vatuniuca (stone of rain) located on Qamea Island, which is believed to have magico-religious properties. It is believed that striking this stone will cause it to rain. Band names also sometimes impart a sense of the importance of these sacred sites to $i$ taukei. For example, composer and performer Simone Vala named his group Miramira ni Vakatabataba after a sacred stone located near his village of Navakawau. He believes that the fingerprints of his family's ancestors (including those of his great-great grandfather, a warrior who won land through battle during the cannibal days) are imprinted upon this stone. ${ }^{28}$

Endemic species of flora are also sometimes celebrated in song, and used as signifiers of local identity. For example, the song "Tagimoucia ga" valorises the tagimoucia (Medinilla Waterhousei), a species of orchid that grows almost exclusively on Taveuni and is hence regarded as being emblematic of Taveuni-ness. Similarly, in sere bass songs (the oldest style of sigidrigi, which began to be superseded by trio during the mid-1990s), it was common to refer to women from particular islands by using a particular species of flora endemic to their island. For example, the tagimoucia refers to women from Taveuni, and the lagakali (Aglaia sattatorum) to women from Lomaiviti.

The ways in which the landscape is represented in sigidrigi songs reveals and shapes $i$ taukei perceptions and conceptions of place. Islands, for example, are consistently

\footnotetext{
${ }^{27}$ These sites include places once settled by the ancestors, where people suffered an unnatural death or were buried, or the abodes of ancestral spirits or cosmological entities (sava) at which they are propitiated and worshipped (Ravuvu 1983:82-3).

28 Similarly, the group Miramira ni Vatuvola, from Vanua Levu, is named after a stone with the ancestor's writing on it (known as Vatuvola). This is located on Dakuniba land, so the group had to ask the people of Dakuniba for permission to use the name. Caucau ni Qaravonu was another band from Vanua Levu. There is a cliff at Nailo where there are turtles carved into the stone inside a cave, and what could be an ancient form of writing carved into the stone on a hillside. The band is named after this place, which is significant to the people of Nailo. It is the yavutu if the gone aiwai (the mataqali of fishermen). Caucau means the morning wind/breeze that comes from inland. This breeze passes Qaravonu before reaching Nailo.
} 
described as ciri yawa (floating on the surface of the ocean, far in the distance). The song "Au mai yabeta tu" ("I came and walked"), for example, contains the lines:

Taveuni kei Koro o Namena ciri yawa

Isa o Benau e ciri koto e yasana
Taveuni and Koro, Namena floating far away

Isa Benau, floating beside me

While this is, indeed, how islands appear to the naked eye when viewed from a distance, this representation contradicts the Western European geological explanation for islands as land masses rising from the sea-bed. Islands are also consistently described as being shrouded in mist/fog (kabu yawa). Songs often describe the natural scenery, with references to swaying coconut palms, waves breaking over the reef, lush vegetation, flowers, mountains, lakes, waterfalls, and white sandy beaches. They may also refer to a place's mild climate and cool breezes, and the beauty of the dawn, sunset, or moonlight. These somewhat idealised representations of Fiji as a 'paradise on earth' are found not only in songs oriented towards overseas tourists, but also in those aimed at local audiences. This particular set of aesthetic values regarding the landscape perhaps reveals the extent to which touristic representations of Fiji have impacted upon $i$ taukei

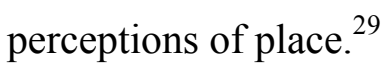

\section{Regional identities}

Sigidrigi songs have not only been used in the construction of intensely local identities; they have also been used to construct regional identities. This can be seen, for example, in the use of local dialects in sigidrigi songs. On Taveuni and Qamea, sere bass ${ }^{30}$ are sung in the Cakaudrove dialect - demonstrating that a process of localisation has occurred over time. While this has been primarily achieved through replacing the consonant ' $\mathrm{k}$ ' with a glottal stop (gato), occasionally Cakaudrove dialect words are substituted for words in the Standard Fijian vocabulary (vakabau).

While some of the musicians I spoke with on Taveuni asserted that sigidrigi is performed in the same way throughout Fiji, others perceived that regional stylistic

\footnotetext{
${ }^{29}$ In songs composed for tourists as well as for local audiences, the friendliness and hospitality of $i$ taukei is emphasised. While songs composed for locals may mention the attractiveness of the young men and women from a particular place, it is mainly in songs composed for male tourists that describe beautiful, sexually available young women.

${ }^{30}$ For example, songs such as "Koi ra na vuda," "Koi au na senimokosoi," "O isa lei karua" and "Dua tiko noqu rosi vulavula talei."
} 
diversity exists. Musicians on Taveuni saw these styles as the result of gradual changes that have taken place over time in various locales, and did not believe that regional styles represented a conscious, ongoing attempt to differentiate various communities. As my research focused primarily on sigidrigi performance on Taveuni, the existence of regional sub-styles can only be supported by anecdotal evidence. These styles are said to be distinguished by factors such as language use, repertoire, as well as vocal and instrumental performance style - including instrumentation, performance techniques, pitch/key, timbre, volume, rhythm, melodic and harmonic structure, the use of particular guitar and ukulele tunings and fingerings, as well as distinctive guitar riffs to introduce and end songs. Further detailed area studies are required before regional stylistic comparisons of sigidrigi performance can be made and then compared with local perceptions of sameness and difference.

\section{National identities}

Nations are imagined communities, as the members "will never know most of their fellow members, meet them, or ever hear of them, yet in the minds of each lives the image of their communion" (Anderson 1983:15). An examination of sigidrigi lyrics and notions regarding ownership reveals how this genre has been used in the expression and construction of the Fijian nation.

Sigidrigi has provided a suitable vehicle for promoting particular representations of Fijian nationhood, as this genre is regarded as being somewhat 'neutral' in that it derives predominantly from non-Fijian sources. Moreover, while meke (a performance genre featuring dance, poetry, costume and music, whose origins predate European contact) are regarded as part of the traditional cultural wealth ( $i$ yau) of particular yavusa, and may only be performed by non-yavusa members with the turaga's (chief's) permission - such strict notions of ownership are not applied to sigidrigi. Additionally, the majority of songs are sung in the lingua franca (va'abau or Standard Fijian). This ensures that the songs appeal to a broad audience, and also evokes the various political mechanisms that facilitated political unity. Sigidrigi can therefore be regarded as an ideal mechanism for symbolically projecting a holistic Fijian ethnicity. However, given that few groups attain nationwide popularity, sigidrigi's importance in terms of developing a sense of national identity appears to be minimal. 
Nevertheless, there are sigidrigi songs that promote Fijian national identity. For example, the legend of the Kaunitoni migration (which narrates the journey of the ancestors of $i$ taukei from Lake Tanganiyika in South Africa to Nakauvadra, Fiji), is narrated in the song "Koi ra na vuda" ("Our ancestors"). This legend has been significant in forging a sense of national identity among Fiji's culturally and linguistically diverse $i$ taukei population.

\section{Verse 1}

Koi ra na vuda, meu tukuni ira E na nodra lako mai Sauca Aferika Isa ko Verata nodra koro dina E na batini drano levu mai Taqaniika Verse 2

Lutunasobasoba e liutaki ira E na nodra lako mai Sauca Aferika Vata kei nai oqori a watina Marama ni ceva dina mai Ijipita Verse 3

Lutunasobasoba e lima na luvena Era kawa turaga tu vei keda Dua wale ga na luvena yalewa Obui Savulu e tiko mai Bureta Verse 4

O Roko Moutu e tiko mai Verata

O Vela Siga mai Burebasaga

O Tui Nayavu mai Batiki raraba

O Dau ni Sai e tiko ma Kabara

Verse 5

Vuni nodra lako mai taqani ika

E na mate lila levu e tauvi ira (disease/starvation?)

Ra soko sivita na wasa talani tika Ra qara vanua e na wasa Pasifika Verse 6

Sa labati ira e dua na cagi laba Era tiko leqaleqa e loma ni waqa Na Kaunitoni vata kei na Duibana Na Kaunitera na yacani nodra waqa Verse 7

Tagi mate o Lutunasobasoba Isa noqu kawa ra sana vakaloloma Noqu kato vatu dina sa mai tasova Ni rau lutu vata kei na kenai vola
Our ancestors, let me tell you

How they travelled from South Africa

Verata their true village

From one side of the lake in Tanganiyika

Lutunasobasoba their leader

In their journey from South Africa

With his wife

Lady from Egypt ${ }^{31}$

Lutunasobasoba has five children

They are our chiefs

Only one daughter

Obui Savulu staying in Bureta (Ovalau)

Roko Moutu staying in Verata

Vela Siga is in Burebasiga

Tui Nayavu in Batiki

Dau ni Sai is in Kabara

The reason they came away

Because of a wasting illness

They crossed the Atlantic Ocean

Looking for a land in the Pacific

A hurricane hit them

They felt unsafe in their canoe In the Kaunitoni and the Duibana

The Kaunitera is the name of their canoe

Lutunasobasoba was wailing Oh my descendents, I feel sorry for you My stone chest has been emptied And it goes with my book ${ }^{32}$

\footnotetext{
${ }^{31}$ This line infers that Lutunasobasoba's wife's beauty equals the Queen of Sheba's.
} 
According to Ilaitia Tuwere (2002:22), this story was unknown before the 1890 s. Since its publication by Basil Thomson (1864:143-6), it has become widely accepted among $i$ taukei, and has become the basis for a sense of national identity based upon the belief of common descent and common geographical point of origin.

Patriotic songs (sere ni vanua) similarly generate a sense of national identity. The national flag has been used in these songs as a national emblem. Following Fijian Independence from Britain in 1970, for example, references to na kuila ni Peritania (the British flag) in songs such as "Isa noqu vanua ko Viti" ("Isa my homeland of Fiji) were replaced with na kuila ni noda vanua (the flag of our land) to reflect Fiji's new political status. Patriotic songs predominantly express pride in Fiji's sporting achievements (particularly those of its national rugby sevens team) and in the activities of its soldiers who have served overseas. Although these songs portray Fiji as a unified, multicultural nation, and emphasise the happiness and friendliness of its people, this representation is belied by songs such as "Melanesia," which concerns the marginalisation of Solomon Islanders in Fiji.

\section{$\underline{\text { Verse } 1}$}

Noqu bula au solia

Meu na colata voli ga

Colacola koa vakataqara

Yacamu au na valataka

Verse 2

Tubutubu era ogataka

Gaunisala me cara wavu me caka

Viti ko sa tiko vinaka

O qai biliga lesu noqu waqa

Chorus

Melanisia soqosoqo au lewena

Au vaqaqara vanua voli

Turaga ni lomani au mai

Kerea meu dei eke

Verse 3

Loma ni lekatu au taubale voli

Tacaqe au lutu au na taubale ga

Ni sa noqu i to ko Jisu

Sa sega vei au na taqaya
I give my life

For me to carry

The responsibility that you allocate

Your name, I will fight for it

The parents were occupied

For the roads and the bridges to be made

Fiji, your well-being

And you push away my boat

Melanesia is my group

I was looking for land

God, grant me mercy

Please let me stay forever

I walk through the jungle

I trip/tumble over and I keep on walking

When Jesus is my guide

I am not scared

\footnotetext{
32 This book contained the accumulated lore of the people, such as knowledge of medicine, weather forecasting, fishing (where to fish, based on the weather and wind direction; how to cut bait), handicrafts, and fortune-telling.
} 


\section{Supranational identities}

The performance of covers of overseas songs in their original languages, as well as the adoption of their stylistic features, enable $i$ taukei to imagine that they belong to supranational communities. Keith Negus (1996: 184) notes that: "a place as the particular, concrete site of the specific social activities does not always coincide with a 'sense of space,' the more abstract way in which we might locate ourself in the world, that 'stretched' sense of where we belong in relation to other parts of the planet.",33 Similarly, Godfrey Baldacchino argues that even the remotest islands can be seen to be marked by the "confluence of juxtaposition of the understanding of local and global realities, or interior and exterior references of meaning, of having roots at home while also deploying routes away" (2005: 247). Those features of sigidrigi that are recognised as having originated overseas provide Taveuni and Qamea musicians with "a means of transcending the limitations of [their] own place in the world, of constructing trajectories rather than boundaries across space” (Stokes 1994: 4).

An example of these kinds of 'trajectories across space' is the sense of panPacific/Oceanic identity generated via the adoption of repertoire from other Pacific Island nations. This is also facilitated through sigidrigi being part of the style complex often referred to as pan-Pacific pop, ${ }^{34}$ which Michael Webb (1993:xix) characterises as a "multi-linked chain of social and cultural identification."

These trajectories can be extended even further. Due to a wide range of media influences, Western culture has come to be linked with concepts of affluence and modernity in the minds of many Taveuni and Qamea islanders - youth in particular. Sigidrigi is regarded as outdated and outmoded by many, whereas newer and more obviously Western music genres have a certain cultural cache. Performing and listening to Western popular songs (for example, from the United States of America and/or Britain), and adopting 'Western' musical instruments and performance practices, enables $i$ taukei to signify their modernity. It enables them to imaginatively 'stretch' their sense of place, and to experience a sense of identification with industrialised/capitalist First World nations. In 'deploying these routes away,' Taveuni

\footnotetext{
${ }^{33}$ See Giddens, 1990; Massey, 1994

${ }^{34}$ See Crowe 1998:139; Kaeppler 1998a:127; Kaeppler 1998b:137; Manuel 1988:236; Freeman Moulin 1998:894; Webb 1998:137
} 
and Qamea islanders are overcoming their sense of cultural cringe and transforming their sense of place.

\section{Conclusion}

In conclusion, this article has woven together theoretical threads from cultural geography, ethnomusicology and popular music studies in order to illustrate the role that sigidrigi has played in shaping how $i$ taukei perceive and conceptualise place. It has shown how this vernacular form of Fijian music is implicated in the construction of communities at geographical scales ranging from the local to the supranational.

An examination of the sigidrigi repertoire and the genre's position in relation to meke has demonstrated how this music has been used to index cultural roots and routes. In other words, it has outlined some of the ways in sigidrigi songs reinforce and perpetuate $i$ taukei attachments to particular places - both at home and abroad. The localised features of this music genre, as well as its long history of performance in Fiji, enable $i$ taukei performers and audience members to index their cultural roots and musically establish a sense of Fijian identity. Yet simultaneously, the features of this music that are recognised as having originated overseas (for example, instruments, repertoire and performance practices) enable $i$ taukei to musically index routes to other identities, and to form supranational imaginative communities. As a hybrid style situated at the nexus between the local and the global, the old and the new, sigidrigi is well placed to reveal some of the current tensions and possibilities linked to Fijian senses of place and identity.

\section{References}

Anderson, B. (1983) Imagined Communities: Reflections on the Origins and Spread of Nationalism, London: Verso.

Baldacchino, G. (2005) 'Editorial: Islands - Objects of Representation,' Geografiska Annaler Series B: Human Geography v87 n4: 247-251

Brewster, A.B. (1922) The Hill Tribes of Fiji, Philadelphia: JB Lippencott.

Chenoweth, V. (1998a) 'Compositional Processes: Irian Jaya,' in Kaeppler, Adrienne L and Love, JW (eds.) The Garland Encyclopedia of World Music: Australia and the Pacific Islands v9, New York and London: Garland Publishing, p. 360. 
(1998b) 'Compositional Processes: New Guinea,' in Kaeppler, AL and Love, JW (eds.) The Garland Encyclopedia of World Music: Australia and the Pacific Islands v9, New York and London: Garland Publishing, pp.357-358.

Crowdy, D. (2005) Guitar Style, Open Tunings, and Stringband Music in Papua New Guinea, Papua New Guinea: Institute of Papua New Guinea Studies.

Crowe, P. (1998) 'Concepts in Oceanic Music: Popular Music - Vanuatu,' in Kaeppler, Adrienne L and Love, JW (eds.) The Garland Encyclopedia of World Music: Australia and the Pacific Islands v9, New York and London: Garland Publishing, pp. 139-140.

Freeman Moulin, J. (1998) 'East Polynesia: Marquesas Islands - New Things,' in Kaeppler, Adrienne L. and Love, JW (eds.) The Garland Encyclopedia of World Music: Australia and the Pacific Islands v9, New York and London: Garland Publishing, p. 894.

Giddens, A. (1990) The Consequences of Modernity, Cambridge: Polity Press.

Glamuzina, K.(1993) Contemporary Music and Performance Practice in Levuka, unpublished MMus (Ethnomusicology) thesis, University of Auckland.

Goldsworthy, D. (1998) 'Fijian Music,' in Kaeppler, Adrienne L and Love, JW (eds.) The Garland Encyclopedia of World Music: Australia and the Pacific Islands v9, New York and London: Garland Publishing, pp. 774-776

Hobsbawm, E. and Ranger, T. (1983) The Invention of Tradition, Cambridge and New York: Cambridge University Press.

Kaeppler, Adrienne L (1998a) 'Popular Music,' in Kaeppler, Adrienne L and Love, JW (eds.) The Garland Encyclopedia of World Music: Australia and the Pacific Islands v9, New York and London: Garland Publishing, pp. 126-128.

Kaeppler, A. L. (1998b) 'Concepts in Oceanic Music: Popular Music - Strings,' in Kaeppler, Adrienne L and Love, JW (eds.) The Garland Encyclopedia of World Music: Australia and the Pacific Islands v9, New York and London: Garland Publishing, pp. 136-7.

Lee, D. S. (1998) 'Music and Dance in Naloto,' in Kaeppler, Adrienne L and Love, JW (eds.) The Garland Encyclopedia of World Music: Australia and the Pacific Islands v9, New York and London: Garland Publishing, pp. 776-781.

Manuel, P. (1988) Popular Music of the Non-Western World: An Introductory Survey, New York and Oxford: Oxford University Press.

Massey, D. (1994) Space, Place and Gender, Cambridge: Polity.

Negus, K. (1996) Popular Music in Theory: An Introduction, Cambridge: Polity Press.

Raven-Hart, R. (1956) "A Village in the Yasawas (Fiji)," Journal of the Polynesian Society v65: 95-154

Ravuvu, A. (1983) Vaka i Taukei: The Fijian Way of Life, Suva: Institute of Pacific Studies.

Stokes, M. (1994) 'Introduction, in Stokes, Martin (ed.) Ethnicity, Identity and Music: The Musical Construction of Place, Oxford: Berg, pp. 1-21.

Teeling, W. (1936) Gods of Tomorrow, London: Lovat Dickson.

Thomson, B. (1864) South Sea Yarns, Edinburgh and London: William Blackwood and Sons. 
Tuwere, I. S (2002) Vanua: Towards a Fijian Theology of Place, Suva and Auckland: Institute of Pacific Studies, University of the South Pacific and College of Saint John the Evangelist.

Webb, M. (1993) Lokal Musik: Lingua Franca Song and Identity in Papua New Guinea, Apwitihire: Studies in Papua New Guinea Musics 3, Boroko: National Research Institute.

(1998) 'Concepts in Oceanic Music: Popular Music - Papua New Guinea,' in Kaeppler, Adrienne L and Love, JW (eds.) The Garland Encyclopedia of World Music: Australia and the Pacific Islands v9, New York and London: Garland Publishing, pp. 137-9.

Whorson, C.W. (1936) Levuka Days of a Parson in Polynesia, London: Society for Promoting Knowledge. 